\title{
Simulation mechanical stress influence to silicon solar cells by Comsol Multiphysics
}

\author{
Botirjon Urmonov ${ }^{1}$, Rayimjon Aliev ${ }^{2}$, Jasurbek Gulomov ${ }^{3}$ \\ ${ }^{1}$ Andijan state university, Uzbekistan, usmonovbotir89@gmail.com \\ ${ }^{2}$ Andijan state university, Uzbekistan, alievuz@yahoo.com \\ ${ }^{3}$ Andijan state university, Uzbekistan, jasurbekgulomov@yahoo.com
}

\begin{abstract}
We know the mechanical properties of silicon. However, little is known about the mechanical properties of silicon solar cells. Modeling is widely used in the study of solar cells. This article discusses in detail the effect of mechanical stress on solar cells. To do this, a model of the solar cell was created and simulated at Comsol Multiphysics. The results were presented visually and graphically. The results were tested for relevance and accuracy.
\end{abstract}

Key words: solar cell, mechanical stress, Comsol Multiphysics, simulation

\section{INTRODUCTION}

Today, the using from renewable energy sources is growing. There are many types of renewable energy sources. Among them, solar cells are used to convert solar energy into electricity. From simple small machinery to large enterprises, everything is powered by electricity. As the demand for electricity increases, efforts are being made to conserve non-renewable energy sources. In addition, the process of obtaining electricity from non-renewable energy sources causes great damage to the environment. That is why many countries are developing programs for the use of renewable energy sources [1-2].

There are many types of solar cells. For example, simple silicon and GaAs-based solar cells. In the 21st century, perovskite and organic solar cellss have also greatly improved. About $95 \%$ of the solar cells produced at the industrial level are silicon-based solar cells. This is because silicon is one of the most common chemical elements in the world [3]. We think it's a good idea to improve silicon-based solar cells. To improve the optical properties of silicon-based solar cells, the optical layers $\mathrm{SiO} 2$ and $\mathrm{SiNx}$ are coated and textured on the surface [4]. Much scientific work is being done to improve the electro-physical and optical properties of silicon-based solar cells. We also studied the mechanical properties of a silicon-based solar cell. Many scientific studies have experimentally studied the effects of mechanical stress on solar panels [5-7].

The study of the mechanical properties of solar cells helps to organize the production process of solar panels. It also helps to accurately assess external influences during their production [11-13].

In the 20th century, a new type of research method, Simulation, was developed. Simulation of physical processes and devices has become one of the main stages of research. There are many models for modeling. For example, Sentaurus TCAD, Silvaco TCAD, Crosslight TCAD, and Cogenda TCAD are available for modeling semiconductor devices [8-10]. In addition, Comsol Multiphysics is used to model an entire system with external influences. We also used the Comsol Multiphysics software package to study the effects of mechanical stress on a silicon-based solar cell.

\section{METHOD}

The effects of mechanical stress on silicon-based solar cells were modeled using the Comsol Multiphysics 5.5 software package. This program has libraries of physical models. These are "Structural mechanics", "Fluid flow", "Electromagnetics", "Chemical engineering", "Acoustics", "Heat transfer" and "Semiconductors". Each library contains specific physical models. If we want to simulate more than one process at a time, we need to use Multiphysics. The focus is on the uniformity of the calculation methods for each process. For example, a time-dependent process and a stationary process cannot be calculated at the same time.

\subsection{Model}

Creating a system model in Comsol Multyphysics is done in 5 steps. These include the creation of a geometric model, the choice of material type, the assignment of physical properties, the construction of a geometric model based on physical properties, and the selection of calculation methods to obtain results. 
A 2D geometric model of the solar cell was created. Because there is symmetry in the solar elements. To create a geometric model, Geometry was created within Component. Of the geometry properties, the unit of length has been changed to $\mathrm{mm}$. Use the Geometry-> Rectangle command to create 5 rectangles. It has been named Antireflection coating, Base Back contact, Front contact 1 and Front contact 2. The width $1 \mathrm{x}$ and the thickness d_SiO2 were given by the width and height properties of the anti-reflective layer. The thickness of the silicon layer is given by d_Si and the width by lx. The top contact was placed every $2.5 \mathrm{~mm}$ and its thickness was given as d_f_ct and width as width_f_ct. The thickness of the back contact is given as the variable d_b_ct. The thickness, width and coordinates of all layers can be seen in .

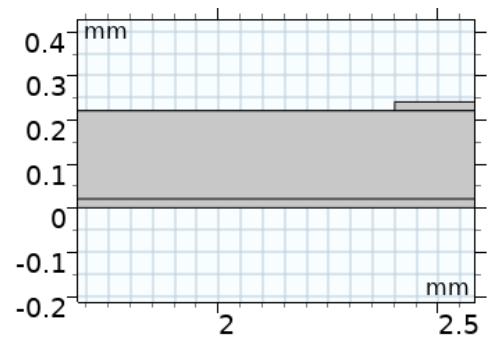

Figure 1. Geometrical model of solar cell

Table 1:Variables

\begin{tabular}{|l|l|l|l|}
\hline d_Si & $\begin{array}{l}0.2 \\
{[\mathrm{~mm}]}\end{array}$ & 2E-4 m & $\begin{array}{l}\text { Thickkness of solar } \\
\text { cell base }\end{array}$ \\
\hline d_f_ct & $\begin{array}{l}0.02 \\
{[\mathrm{~mm}]}\end{array}$ & $2 \mathrm{E}-5 \mathrm{~m}$ & $\begin{array}{l}\text { Thickness of solar cell } \\
\text { front contact }\end{array}$ \\
\hline d_b_ct & $\begin{array}{l}0.02 \\
{[\mathrm{~mm}]}\end{array}$ & $2 \mathrm{E}-5 \mathrm{~m}$ & $\begin{array}{l}\text { Thickness of solar cell } \\
\text { back contact }\end{array}$ \\
\hline d_SiO2 & $\begin{array}{l}0.0001 \\
{[\mathrm{~mm}]}\end{array}$ & $1 \mathrm{E}-7 \mathrm{~m}$ & $\begin{array}{l}\text { Thickness of } \\
\text { antireflection coating } \\
\text { of solar cell }\end{array}$ \\
\hline width_f_ct & $\begin{array}{l}0.2 \\
{[\mathrm{~mm}]}\end{array}$ & $2 \mathrm{E}-4 \mathrm{~m}$ & width of front contact \\
\hline width_sc & $\begin{array}{l}10 \\
{[\mathrm{~mm}]}\end{array}$ & $1 \mathrm{E}-2$ & Solar cell width \\
\hline
\end{tabular}

To model the effect of mechanical stress, a physical model, Solid Mechanics, was selected from the Structural Mechanics group of physical properties. If we want to give strength to a surface, we add Boundry Load from the context menu of Solid Mechanics to the physical properties. If we want to give strength to 2 or more surfaces in the same amount and direction, we can add a single Boundry Load. it is enough to add the surfaces we want to give it strength. If we want to give different strengths to different surfaces, we have to add one Boundry Load for each force. If we want to immobilize any part of the system we are modeling, we add Fixed constraint from the context menu, and the immovable part is given this property.

Based on the physical properties given above, we network the whole system. The purpose of this is that we know that the calculation is done in a numerical style. Also, if we network the system, we will be able to determine the values for each network node. This means that the smaller the grid, the more accurate the calculation. But the computational speed decreases.

By varying the value of the force or mechanical stress acting on a silicon-based solar cell, it is possible to determine its mechanical characteristics under different forces.

\subsection{Theory}

Comsol calculates based on the numerical method. Also, in the simulation of 2- and 3-dimensional physical processes are obtained depending on the coordinate axis of the physical equations. We know that physics uses time-dependent equations to describe general processes. Time equations are general equations for these processes. If we say that all parameters and variables are independent of time, then stationary equations are formed. Hence, stationary equations are special cases of time-dependent equations.

$$
\nabla S+F_{v}=0
$$

Here: $S$ - mechanical stress, $F_{v}-$ volume force.

We know that if we put force on a body, the opposite force will appear in the opposite direction. This force is called volumetric force. The sum of the gradient of volumetric force and mechanical stress is zero at stationary state (Formula 1).

$$
S=S_{\text {add }}+C: \varepsilon_{e l}(2)
$$

Here: $S_{\text {add }}-$ additional mechanical stress, $\varepsilon_{\mathrm{el}}-$ relative mechanical expansion, $\mathrm{C}$ : - constructor

The total mechanical stress and the relatively elastic elongation are connected by a design tensor (Formula 2).

$$
\varepsilon_{a l}=s-\varepsilon_{\text {in } a l} \text { (3) }
$$

Here: $\varepsilon-$ total mechanical expansion, $\varepsilon_{\text {inel }}-$ inelastic mechanical exansion.

$$
\varepsilon_{\text {inel }}=\varepsilon_{0}+\varepsilon_{\text {ext }}+\varepsilon_{o t h}(4)
$$

Here: $\varepsilon_{0}$ - initial mechanical expansion, $\varepsilon_{\mathrm{ext}}-$ extrenal mechanical expansion, $\varepsilon_{\text {oth }}$ - other mechanical expansion

Formula 4 was used in Comsol to determine the amount of inelastic relative elongation. Other effects are also taken into account.

$$
S_{a d d}=S_{0}+S_{a x t}+S_{a q}
$$

Here: $S_{0}$ - initial mechanical stress, $S_{\text {ext }}$ - external mechanical stress, $\mathrm{S}_{\mathrm{q}}-$ other mechanical stress

$$
\begin{array}{r}
\varepsilon=\frac{1}{2}\left[(\nabla u)^{T}+\nabla u\right] \\
C=C(E, v)
\end{array}
$$

Here: $u$ - field of mechanical stress, $\mathrm{E}-$ Yung modulus, $v$ -poison ratio.

\section{RESUlts}

Our goal is to study the distribution of the force acting on the solar cell throughout the solar cell and its effect on its properties. If we look at the results of many studies, the mechanical properties of solar cells are poorly understood. We virtually created a model of a silicon-based solar cell 
using the Comsol Multiphysics program. Then we applied a force of 2 Newtons perpendicular to its surface. We can see the deformation of its surface (Figure 2). In the model, we were exposed to a body with a diameter of $0.1 \mathrm{~mm}$. The body penetrated the solar cell to a depth of $10 \mu \mathrm{m}$ under a force of 2 Newtons.

We can see the effect of the force on the depth distribution (Figure 3). We know that the solar cell has two layers in its simplest form. The first layer is $n$ spheres and the second layer is $\mathrm{p}$ spheres. $\mathrm{n}$ field thickness $10 \mu \mathrm{m}$. the amount of mechanical stress increases to the boundary of the $n$ and $p$ spheres. The $p-n$ junction is the point of change of the mechanical stress. After the $\mathrm{p}-\mathrm{n}$ junction, the amount of mechanical stress decreases exponentially. This means that there is an exponential relationship between mechanical strength and thickness.

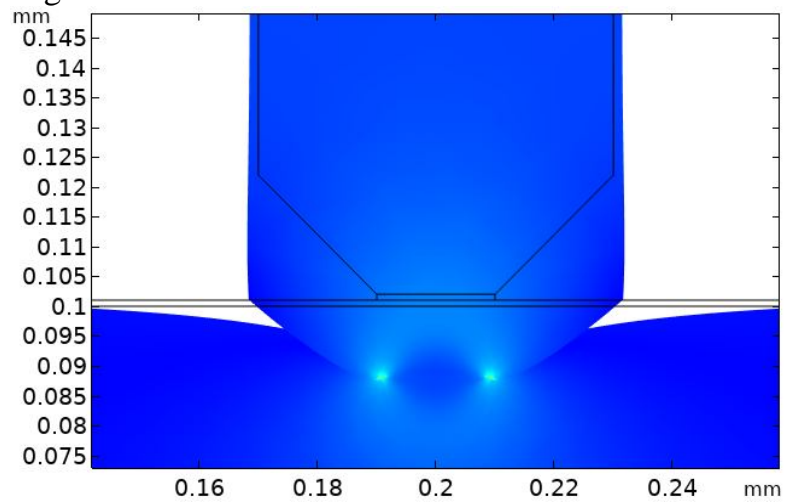

Figure 2. A $2 d$ graph that visualizes the distribution of force on a solar cell by its size

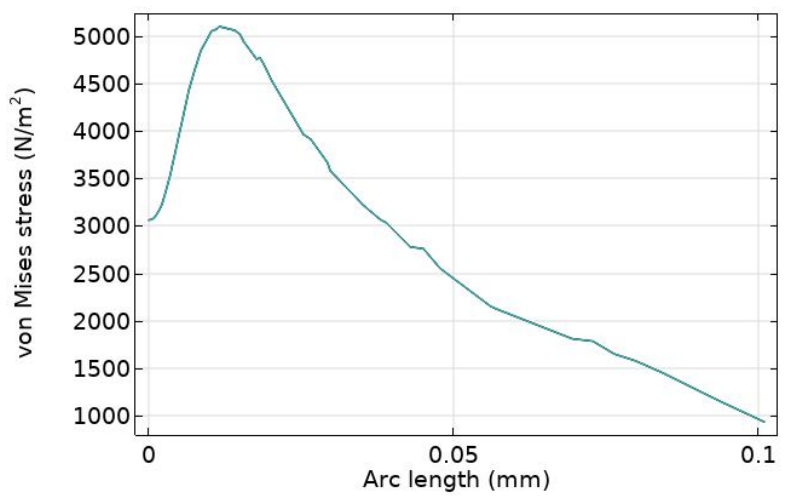

Figure 3. Depth distribution of $0.2 \mathrm{~N}$ force applied to a silicon-based solar cell

The change in the effect of the force on the surface of the solar cell is given in (Figure 4). The mechanical stress is highest at the corners of the body exposed to the solar cell. There is minimal mechanical stress in the middle. The effect of external forces on the body is greatly reduced.

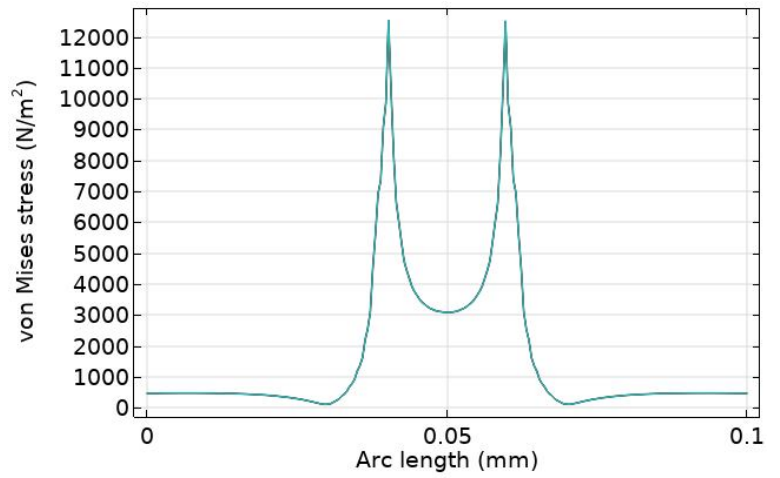

Figure 4. The distribution of the force exerted on a solar cell by its surface

\section{Discussion}

The results show that the effect of mechanical force on the solar cell is significant. We know that every device and material has a strength limit. There is also a limit to the durability of the solar element. From the above result, the introduction of silicon also affects its mechanical properties. Because the thickness of the solar cells is so thin, the strength limit is very small. Therefore, it is covered with an EVA layer to protect it from external influences. Note that (Figure 3) is the exponential function that decreases after the maximum point of the graph. If we look at the Weibull distribution determined experimentally, we can see that the relative stress is exponentially related to the mechanical stress. This proves that the results we obtained through modeling are close to the results of real experiments [13-14].

$$
P\left(\sigma_{i}\right)=1-\left[\exp \left(-\frac{\sigma_{i}}{\sigma_{q}}\right)^{m}\right]
$$

Here: $\sigma_{\mathrm{i}}-$ mechanical stress, $\sigma_{\theta}, \mathrm{m}-$ Weibull constants.

\section{CONCLUSION}

In studying the mechanical effects on the solar system, we have concluded the following:

1. The study of the limits of the forces acting on the solar cell correctly organizes the process of their production.

2. A change in the nature of the effect of mechanical stress on the p-n junction has been identified.

3. The mechanical stress increases up to the P-n junction and then decreases exponentially.

4. From the visualized results, the distribution of voltage across the surface of the solar cell is sharply reduced..

\section{ACKNOWLEDGEMENT}

The authors would like to thank the staff of the Renewable Energy Research Laboratory of Andijan State University for their close assistance in writing this article.

\section{REFERENCES}

[1] D. Berney Needleman, J. R. Poindexter, R. C. Kurchin, I. M. Peters, G. Wilson, and T. Buonassisi, "Economically 
sustainable scaling of Photovoltaics to meet climate targets," Energy Environ. Sci., Apr. 2016.

[2] International Energy Agency, "Energy and Climate Change: World Energy Outlook Special Report," 2015.

[3] Reich, N.H., Sark, W.G.J.H.M.V., Alsema, E.A., Lof, R.W., Schropp, R.E.I., Sinke, W.C., Turkenburg, W.C., 2009. Crystalline silicon cell performance at low light intensity. Sol. Energy Mater. Sol. Cells 93, 1471-1481.

[4] Jasurbek Gulomov, Rayimjon Aliev, Murodjon Abduvoxidov, Avazbek Mirzaalimov, Navruzbek Mirzaalimov. Exploring optical properties of solar cells by programming and modeling. Global Journal of Engineering and Technology Advances [Internet]. GSC Online Press; 2020 Oct 30;5(1):032-038. Available from: http://dx.doi.org/10.30574/gjeta.2020.5.1.0080

[5] M. Sander, S. Dietrich, M. Pander, M. Ebert, J. Bagdahn, Systematic investigation of cracks in encapsulated solar cells after mechanical loading, Solar Energy Materials and Solar Cells 111 (2013) 82-89.

[6] Pingel S, Zemen Y, Geipel T, Berghold J. Mechanical stability of solar cells within solar panels. Proc. 24th European Photovoltaic Solar Energy Conf., Hamburg, Germany; 2009, pp. 3459-3463.

[7] Assmus M, Jack S, Weiss KA, Koehl M. Measurement and simulation of vibrations of PV-modules induced by dynamic mechanical loads. Progress in Photovoltaics: Research and Applications 2011;doi:10.1002/pip.1087

[8] Rayimjon Aliev, Murodjon Abduvoxidov, Navruzbek Mirzaalimov, and Jasurbek G'Ulomov. "KREMNIY ASOSLI QUYOSH ELEMENTLARIDA REKOMBINATSIYA VA GENERATSIYA JARAYONI" Science and Education, vol. 1, no. 2, 2020, pp. 230-235. doi: http://dx.doi.org/10.24412/2181-0842-2020-2-230-235

[9] Jasurbek Gulomov, Rayimjon Aliev, Murad Nasirov and Jakhongir Ziyoitdinov (2020); MODELING METAL NANOPARTICLES INFLUENCE TO PROPERTIES OF SILICON SOLAR CELLS Int. J. of Adv. Res. 8 (Nov). 336-345. Doi: http://dx.doi.org/10.21474/IJAR01/12015

[10]Aliev, R., Gulomov, J., Abduvohidov, M. et al. Stimulation of Photoactive Absorption of Sunlight in Thin Layers of Silicon Structures by Metal Nanoparticles. Appl. Sol. Energy 56, 364-370 (2020). https://doi.org/10.3103/S0003701X20050035

[11] V.A. Popovich, M. Janssen, I.J. Bennett, Breakage issues in silicon solar wafers and cells, Photovoltaics International 12 (2011) 49-57.

[12] S. Schoenfelder and J. Bagdahn and M. Petzold and J. Burghartz, "Mechanical Characterisation and Modelling of Thin Chips" in Ultra-thin Chip Technology and Applications, New York, Springer, pp. 195-218 (2011)

[13] F. Kaule and W. Wang and S. Schoenfelder, "Modeling and testing the mechanical strength of solar cells" in Solar Energy Materials and Solar Cells, (2014)

[14] W. Weibull, A Statistical Theory of the Strength of Materials, Ingeniörsvetenskapsakademiens Handlingar
Nr. 151, Generalstabens Litografiska Anstalts Förlag, Stockholm, 1939.

[15] W. Weibull, A statistical distribution function of wide applicability, Journal of Applied Mechanics 18 (1951) 293-297. 